$1-1-1988$

\title{
Chronicling a Movement for Civil Rights
}

James W. Ellis

University of New Mexico - School of Law

Follow this and additional works at: https://digitalrepository.unm.edu/law_facultyscholarship

Part of the Law Commons

\section{Recommended Citation}

James W. Ellis, Chronicling a Movement for Civil Rights, 22 Law \& Society Review 1027 (1988).

Available at: https://digitalrepository.unm.edu/law_facultyscholarship/565

This Article is brought to you for free and open access by the UNM School of Law at UNM Digital Repository. It has been accepted for inclusion in Faculty Scholarship by an authorized administrator of UNM Digital Repository. For more information, please contact amywinter@unm.edu, Isloane@salud.unm.edu, sarahrk@unm.edu.

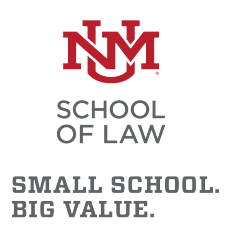

BIG VALUE. 


\title{
CHRONICLING A MOVEMENT FOR CIVIL RIGHTS
}

\author{
JAMES W. ELLIS
}

Samuel Jan Brakel, John Parry, and Barbara A. Weiner. The Mentally Disabled and the Law, 3rd ed. (Chicago: American Bar Foundation, 1985). xii + 845 pp. Tables, bibliography, index. $\$ 75.00$

The history of the modern movement for civil rights for people with mental disabilities is chronicled in the three editions of the American Bar Foundation's treatise, The Mentally Disabled and the Law. Each presents a snapshot of the status of the law at the time of its publication. Taken together, they provide an overview of the extent of the movement's successes and the speed with which they have been attained in recent years. The first edition, published in 1961, describes the law as it had developed during the years following World War II, and argues that it has been "an opportune time to re-evaluate the law" (Lindman and McIntyre, 1961: 14) and to bring it into conformity with modern scientific understanding of the nature of mental disability and contemporary public opinion concerning individual rights (Ibid.). The second edition, published in 1971, recounts the changes that had taken place in the $1960 \mathrm{~s}$, primarily the increasing federal activity in the field of mental disability, as well as scattered developments in state case law and legislation. But its authors again conclude that "[t]he factors conducive to a thorough examination and reevaluation of the laws as they relate to the rights of the mentally disabled exist today to a greater extent than ever before" (Brakel and Rock, 1971: 8).

This observation was certainly prophetic. The 1970 s and early 1980s witnessed a sea of change in the law's approach to people with mental disabilities. ${ }^{1}$ In countless cases, federal and state courts found institutional conditions and state legislation that limited the rights of people with mental illness and mental retardation to be unconstitutional. As a result of such litigation (or its threat), every state overhauled its laws. The transformation was remarkably swift and thorough.

The process by which these changes have been accomplished

1 Indeed, a noted authority in the area has observed, "Give or take a year or two, the birth of mental health law as a discrete discipline probably occurred about 1970 (Wexler, 1981: 2).

LAW \& SOCIETY REVIEW, Volume 22, Number 5 (1988) 
are beginning to be examined by other scholars (Rothman and Rothman, 1984; Braddock, 1987; Milner, 1987; Scotch, 1984). The goal of the third edition of this treatise, as with its predecessors, is to describe the state of the law. The twelve chapters focus on major topics such as involuntary hospitalization, guardianship, family law, rights in the community, and criminal law. The centerpiece of each chapter is a series of charts that detail the topic's statutes in the fifty states and the District of Columbia. The text accompanying the charts in each chapter discusses those statutes and also describes trends in case law. Unlike previous editions, the individual authorship of each chapter is identified.

The current edition ${ }^{2}$ is an unmatched and indispensable source of information concerning the current state of mental disability law. The reader who wants an overview of a particular area of mental disability law will find the text of its chapters a useful starting point. The reader interested in general developments in the states will find a wealth of information in the fifty-seven statutory tables. These charts are, for the most part, logically organized and are arranged in as user-friendly a format as possible. In addition, a separate chapter and the introduction to each topical chapter provide historical background that is detailed and helpful.

The most remarkable feature of this volume is the dissimilarity of its contents from that of its predecessors. The first difference is the sheer volume of the material. In addition to transforming the content of mental disability law, the events of the last fifteen years have magnified its complexity and detail. Even professionals and scholars who work regularly in this field are likely to be surprised at how much change has taken place, especially at the state level.

The changes in statutes and case law have not been ideologically random or neutral, of course, and therein lies a significant difficulty with the current edition. Judges and legislators have transformed mental disability law with an eye toward recognizing more clearly the substantive rights of individuals who are mentally ill or mentaliy retarded, and providing adequate procedural protections to ensure those rights. The changes documented here constitute a full-fledged civil rights movement, fully equivalent in its impact on the lives of persons with mental disabilities to its counterparts in the areas of race and gender. The authors clearly disagree among themselves on the extent to which they endorse those changes.

In particular, the chapters authored by Brakel, which include the crucial areas of involuntary institutionalization, voluntary admission, discharge and transfer, and family law, betray an ill-disguised hostility toward many of the rights now generally recog-

2 The third edition bears a 1985 publication date, but actually appeared in 1986. 
nized for mentally disabled persons. A few examples will suggest the scope of the problem. Noting the phenomenon that many have observed (Warren 1982) that rights won in court or the legislature may not be implemented in practice, Brakel adopts the view that this demonstrates that the legal protections are impractical and unnecessary. He indicates sympathy with the view that these rights are "an unwieldy, obstructionist mass of procedural 'junk' that only inhibits the effort to protect" (p. 28). Similarly, he refers to those who express concern over the fact that most persons admitted under provisions for voluntary patients are actually coerced as "legal perfectionists" (p. 180). Brakel also indicates his disdain for the developments he recounts by placing such terms as "rights" and "equal" in quotation marks (p. 5).

Brakel's animosity to the rights of disabled persons is not shared by his co-authors, ${ }^{3}$ who applaud recent developments in the areas about which they write, and occasionally call for further reforms (for example, Weiner, p. 251, Parry, p. 435). But for the key subjects discussed in Brakel's chapters, it is at least a distraction. And despite Brakel's efforts to report developments straightforwardly, less knowledgeable readers may encounter difficulty in understanding some of the phenomena. ${ }^{4}$ For example, a reader unfamiliar with the field might be puzzled by the courts' and legislatures' sudden insistence on enhanced procedural protections in civil commitment if he or she were unaware of the revelations about abominable institutional conditions that occurred at about the same time (and that are described in Weiner's chapter on the rights of institutionalized persons).

The book is also marred by smaller problems. ${ }^{5}$ The authors differ in the extent to which they treat people with mental retardation as coequal subjects rather than as an afterthought to discussions of mental illness. Parry and Weiner are more conscientious (or knowledgeable) on this score than Brakel. ${ }^{6}$ The chapters are also uneven in their use of material from model statutes and stan-

3 Or, as full disclosure requires, by this reviewer.

4 I do not mean to suggest that only cheerleaders for a phenomenon are entitled to describe its history or current practice. One might imagine a treatise on death penalty statutes by Anthony Amsterdam or on modern equal protection jurisprudence by Chief Justice William Rehnquist that would be equivalent to the chapters under discussion, and that could be valuable contributions to the literature. But as in this case, the reader of such a work would be well-advised to keep the author's perspective in mind when evaluating the work's descriptions and analyses.

5 It should not be surprising that some citation errors would inevitably creep into a volume that has more than $\mathbf{4 6 0 0}$ footnotes; nevertheless it is disquieting that the text repeatedly inverts the parties' names in the two leading United States Supreme Court cases in the field, O'Connor v. Donaldson, 422 U.S. 563 (1975) and Youngberg v. Romeo, 457 U.S. 357 (1982) (35, 188, 336, 347).

6 Brakel's chapters, however, provide richer historical background and those of Brakel and Parry provide more sophisticated case analysis than other chapters sometimes achieve. 
dards that are now available. ${ }^{7}$ There are also minor problems with the charts; it is impossible for a reader to know what the cutoff date was for the information in a particular statutory table. The introduction notes that the cutoff date for "most" was October of 1982 , but that some were updated to 1983 or 1984 . Some readers may have occasion to wish they knew which was which. Finally, the "select bibliography" is too brief and idiosyncratic in its inclusions and omissions to be useful. The reader would be better advised to use the wealth of sources in the footnotes within individual chapters as a guide for further research.

None of these problems is sufficient to detract from the remarkable achievement of the authors in compiling this monumental reference work, which was recently awarded the prestigious Manfred S. Guttmacher Award by the American Psychiatric Association. This new edition is an essential starting point for anyone doing research in this area, and an indispensable volume in any disability scholar's library.

What developments are likely to be emphasized if a fourth edition of this work is published in another ten years? It seems likely that the focus on institutions will be reduced even further, and that more attention will be directed to protection of the rights of clients who live in their own communities. ${ }^{8}$ A group of clients likely to receive increased attention are the so-called "dual-diagnosis" individuals, who are both mentally ill and mentally retarded (p. 18, note 49). Despite the setback of the Supreme Court's decision in Parham v. J.R., 442 U.S. 584 (1979), attention is also likely to return to the difficult issues posed by mentally disabled minors. In criminal law, courts are likely to turn their attention increasingly to the problems presented by defendants with mental retardation. And in all areas, judges are likely to rely more frequently on provisions of state constitutions in adjudicating the rights of persons with disabilities (Meisel, 1982).

Whatever events lie ahead in this field, 9 I certainly hope the American Bar Foundation will follow this valuable work with new editions at appropriate intervals.

7 The earlier editions made profitable use of the National Institute of Mental Health's Draft Act for the Hospitalization of the Mentally Ill. The chapters by Weiner and Brakel fail to make equivalent use of modern model statutes (Mental Health Law Project, 1977-78; Sales et al., 1982) and standards (American Bar Association, 1984).

8 As increasing numbers of disabled students graduate from the education to which they are now entitled under the Education for All Handicapped Children Act (Pub. L. 94-142), more attention will be directed to programs assisting their transition from school to adult life in the community.

9 Brakel predicts the possibility of a "steep decline in legal activity in the mental disability field" (p. 23). No evidence of this dropoff has appeared, and the new availability of protection and advocacy services for persons with mental illness seems to point in the other direction. Brakel is likely to be disappointed. 
JAMES W. ELLIS is a Professor of Law at the University of New Mexico and President-elect of the American Association on Mental Retardation. He holds an A.B. from Occidental College (1968), and a J.D. from the University of California at Berkeley (1974). His recent publications include "Mentally Retarded Criminal Defendants," 53 George Washington Law Review 414 (1985) (with Ruth Luckasson), and "The Consequences of the Insanity Defense: Proposals to Reform Post-acquittal Commitment Laws," 35 Catholic University Law Review 961 (1986).

\section{REFERENCES}

AMERICAN BAR ASSOCIATION (1984) "Mental Health Criminal Justice Standards," Chapter 7, American Bar Association Standards for Criminal Justice, $2 \mathrm{~d}$ ed. Boston: Little, Brown.

BRADDOCK, David (1987) Federal Policy toward Mental Retardation and Developmental Disabilities. Baltimore: Paul $H$. Brookes.

BRAKEL, Samuel J., and Ronald S. ROCK (1971) The Mentally Disabled and the Law, revised ed. Chicago: University of Chicago Press.

LINDMAN, Frank T., and Donald M. McINTYRE, Jr. (1961) The Mentally Disabled and the Law. Chicago: University of Chicago Press.

MEISEL, Alan (1982) "The Rights of the Mentally Ill under State Constitutions," 45 no. 3 Law and Contemporary Problems 7.

MENTAL HEALTH LAW PROJECT (1977-78) "Legal Issues in State Mental Health Care: Proposals for Change," 2 Mental Disability Law Reporter 55, $265,439,613$.

MILNER, Neal (1987) "The Right to Refuse Treatment: Four Case Studies of Legal Mobilization," 21 Law \& Society Review 447.

ROTHMAN, David, and Sheila ROTHMAN (1984) The Willowbrook Wars. New York: Harper and Row.

SALES, Bruce D., D. Matthew POWELL, and Richard VAN DUIZEND (1982) Disabled Persons and the Law: State Legislative Issues. New York: Plenum Press.

SCOTCH, Richard K. (1984) From Good Will to Civil Rights: Transforming Federal Disability Policy. Philadelphia: Temple University Press.

WARREN, Carol (1982) The Court of Last Resort: Mental Ilness and the Law. Chicago: University of Chicago Press.

WEXLER, David B. (1981) Mental Health Law: Major Issues. New York: Plenum Press.

\section{CASES CITED}

O'Connor v. Donaldson, 422 U.S. 563 (1975).

Parham v. J.R., 442 U.S. 584 (1979).

Youngberg $v$. Romeo, 457 U.S. 357 (1982). 